\title{
B-Cell Aplasia
}

National Cancer Institute

\section{Source}

National Cancer Institute. B-Cell Aplasia. NCI Thesaurus. Code C162941.

A condition characterized by extremely low B-cell counts. It occurs when anti-CD19 CAR

T-cells attack and kill CD19-expressing B-lymphocytes. 